\title{
LUKISAN MANUSIA DI PULAU LOMBLEN, FLORES TIMUR (TAMBAHAN DATA HASIL SENI BERCORAK PRASEJARAH)
}

\author{
Oleh: Sumiati AS.
}

Dalam masa prasejarah Indonesia, hasrat manusia untuk mengekspresikan keindahan, muncul ketika manusia mulai hidup semi menetap di dalam gua-gua. Ekspresi keindahan tersebut, dituangkan dalam bentuk seni lukis, yang diterapkan pada dinding-dinding gua atau dinding-dinding batu. Hasil seni di atas selain sebagai usaha untuk mengekspresikan keindahan dimungkinkan pula sebagai ekspresi yang menggambarkan pengalaman, perjuangan, dan harapan hidupnya. Lukisan itu pada umumnya dibuat dengan warna merah, kemudian warna hitam, dan warna putih. Obyek yang dilukis antara lain berupa; cap-cap tangan, babi rusa, binatang melata, perahu dan lain sebagainya.

Ekspresi hasrat manusia akan keindahan tercermin pula dalam seni relief dan seni patung, terutama pada masa kehidupan manusia telah benarbenar menetap, yaitu pada masa perundagian. Seni relief dapat diketahui kehadirannya dengan adanya gambar-gambar yang dipahatkan pada wadah-wadah kubur, seperti misalnya sarkofagus, dan waruga. Sedang seni patung dapat dirunut kembali datanya dengan adanya temuan patungpatung bercorak megalitik, misalnya di daerah Pasemah (Sumatra Selatan), di daerah Bada (Sulawesi Tengah), dan daerah Gunung Kidul (Daerah Istimewa Yogyakarta).

Hasil seni prasejarah baik yang berupa lukis, seni relief, maupun seni patung tidak hanya bertujuan untuk mengekspresikan keindahan belaka, tetapi memiliki pula nilai-nilai magis religius. Oleh karena itu gaya karya seni prasejarah ditentukan pula oleh faktor-faktor yang mendukung penampilannya. Faktor itu antara lain adalah kepercayaan. Bertolak dari anggapan itu, maka hasil-hasil seni tersebut di atas dalam penggambarannya kurang memperhatikan ketepatan anatomi serta proporsinya. Unsur yang diutamakan adalah segi simbolisnya, sehingga hasil seni prasejarah dalam penggambaran obyeknya lebih menonjolkan arti simbolisnya, dari pada ketepatan anatomis proporsinya. Sebagai contoh misalnya dalam menggambarkan motif manusia.

Motif manusia sering pula digambarkan antropomorfis dengan gaya kangkang, atau motif manusia dengan kepala besar, atau dengan genetalia yang menonjol. Bahkan sering pula motif manusia digambarkan hanya diwakili oleh bagian-bagian tertentu dari tubuh manusia. Bagian-bagian tubuh 
tersebut, dipilih dari bagian tubuh yang dianggap memiliki kekuatan magis lebih banyak, bila dibandingkan dengan bagian-bagian tubuh lainnya. Bagian-bagian itu, antara lain bagian muka dan mata.

Hasil seni bercorak prasejarah, ditemukan pula di desa Lemagute, kecamatan Ile Ape, kabupaten Flores Timur. Lukisan itu berupa motif manusia yang memiliki ciri proporsi kurang seimbang, serta genetalianya digambarkan menonjol.

\section{II}

Desa Lemagute berada tidak jauh dari pantai laut Flores, kira-kira berjarak $100 \mathrm{~m}$ dari garis pantai. Pulau Lomblen terletak antara $8^{\circ} 10^{\circ}$ - $10^{0} 35^{\prime}$ Lintang Selatan dan antara $123^{\circ} 36^{\prime}-36^{\circ} 40^{\prime \prime}-123^{\circ} 54^{\prime} 10^{\prime \prime}$ Bujur Timur. Ditinjau dari segi arkeologis pulau Lomblen baru mulai dikenal pada tahun 1961, dengan adanya temuan kubur tempayan oleh Verhoven. Selain kubur tempayan tersebut, ternyata pulau itu memiliki pula bendabenda lain, misalnya moko, pecahan gerabah, keramik asing, ${ }^{*}$ dan lukis pada dinding batu. Lukisan tersebut berupa motif manusia dan motif perahu.

Lukisan motif manusia berada pada salah satu permukaan batu andesit, berukuran tinggi kira-kira $6 \mathrm{~m}$, lebar $\pm 4 \mathrm{~m}$. Motif manusia tersebut digambarkan dengan warna merah, yang dioleskan pada seluruh permukaan obyek yang dilukis. Pada masa sekarang warna merah itu, sudah tidak begitu jelas. Dapat diperkirakan bahwa lukisan itu, dibuat dengan cara mengoleskan warna merah dengan menggunakan kuas pada seluruh obyek yang dilukis. Kuas yang digunakan diperkirakan dibuat dari bambu yang dipukul-pukul hingga lunak dan menghasilkan serat, atau menggunakan kuas rambut manusia, seperti halnya yang dilakukan oleh suku Aborigin di Australia (Elkín, 1954: 234).

Motif manusia digambarkan dalam posisi berdiri dengan kaki direntangkan ke samping, telapak kaki mengarah ke luar dengan lima jari-jarinya. Kemaluan menonjol dan menunjukkan milik laki-laki. Kedua tangan berada di samping badan, dan mulai siku agak dilipat, sehingga kedua tangan tersebut masing-masing berada di atas pinggul. Telapak tangan terbuka, lengkap dengan kelima jari-jarinya. Bagian mulut, mata, alis dan hidung tidak digambarkan, sedang telinga hanya berupa tonjolan. Pada kepalanya terdapat tonjolan, mungkin menggambarkan topi yang meninggi. Secara keseluruhan lukisan manusia itu memiliki tinggi $80 \mathrm{Cm}$, panjang kaki $30 \mathrm{~cm}$, panjang tangan $30 \mathrm{~cm}$, panjang badan $30 \mathrm{~cm}$ sedang tangan kiri $27 \mathrm{~cm}$. Berdasarkan ukuran tersebut, dapat diketahui bahwa lukisan manusia itu, memiliki proporsi yang kurang seimbang karena antara badan, dan tangan digambarkan sama panjangnya. Sedang kakinya tampak lebih pendek dari

* Moko, pecahan gerabah, keramik asing dan lukisan dinding batu adalah survei Pusat Penelitian Arkeologi Nasional, di bawah Pimpinan D.D. Bintartitahun 1982. 
kenyataan, karena penggambaran telapak kaki besar, dan tidak sama bentuk dan besarnya antara telapak kaki kiri dan kanan, demikian pula antara telapak tangan kiri dan kanan. Kesan pendek dipertegas oleh penggambaran bagian paha yang pendek dan besar.

Seperti halnya lukisan manusia, lukisan perahu juga dilukiskan pada permukaan batu andesit, yang letaknya kira-kira $5 \mathrm{~m}$ di sebelah barat daya lukisan yang pertama. Motif perahu hanya dilukiskan bagian luarnya, dengan garis yang berwarna putih, garis-garis tersebut hampir sama, kirakira $1 \mathrm{~cm}$. Dengan demikian dapat diperkirakan bahwa alat yang digunakan untuk melukis, adalah kuas yang tidak terlalu besar. Mungkin pula kuas yang digunakan juga dibuat dari bambu atau rambut, seperti halnya yang digunakan untuk membuat lukisan motif manusia. Perbedaannya adalah ukuran kuasnya, kemungkinan kuas yang digunakan untuk melukis motif manusia mempunyai ukuran yang lebih besar.

Secara keseluruhan motif perahu tersebut, menunjukkan bentuk yang tidak lengkap, karena bagian buritan menunjukkan tanda-tanda tidak selesai. Motif perahu itu digambarkan memiliki layar, dengan tiang layarnya berjumlah tiga buah. Selain layar dilukiskan pula 5 buah dayung, yang ukurannya tidak sama. Ujung dayung yang berdekatan dengan haluan, mempunyai ukuran paling besar, bila dibanding dengan ujung dayung lainnya. Lukisan itu panjangnya $60 \mathrm{~cm}$, lebar $13 \mathrm{~cm}$, sedang panjang layar $53 \mathrm{~cm}$, lebar layar $22 \mathrm{~cm}$, dan tinggi tiang layar adalah $30 \mathrm{~cm}$. Dilukiskan pada batu berukuran tinggi $3 \mathrm{~m}$, dan lebar $3,5 \mathrm{~m}$.

Dari uraian di atas, dapat diketahui bahwa ke dua motif tersebut, dibuat dengan cara dilukis. Cara tersebut merupakan salah satu cara membuat lukisan pada dinding gua atau batu. Menurut Van Heekeren lukisan dinding gua pada umumnya dibuat dengan cara dilukis, dipercik atau digores (van Heekeren, 1950: 26). Dari dua lukisan tersebut, uraian selanjutnya hanya ditekankan pada lukisan motif manusia.

\section{III}

Di luar pulau Lomblen lukisan yang berupa motif manusia ditemukan di beberapa tempat, misalnya Irian Jaya, pulau Seram, dan pulau Kei. Motif manusia tersebut dilukiskan pada dinding-dinding gua atau dinding batu karang. Motif manusia sering pula diekspresikan dalam bentuk seni relief pada dinding wadah kubur, misalnya pada waruga, pandhusa, dan sarkofagus (Soejono, 1977: 144-145). Ekspresi motif manusia dikenakan pula pada kain, misalnya kain tenun dari Sumba, dan pakaian manik-manik dari daerah Kalimantan (Hoop, 1949: 92-95). 
Untuk memperoleh gambaran yang jelas, akan diuraikan beberapa contoh motif manusia baik sebagai hasil seni lukis, seni relief, maupun sebagai hasil tenun. Sebagai contoh adalah lukisan motif manusia di pulau Seram, di sepanjang teluk Seleman. Di antara lukisan yang ditemukan di daerah tersebut, terdapat motif manusia dengan perisai pada tangan kirinya, sedang tangan kanan tidak digambarkan secara lengkap. Motif manusia ini digambarkan dalam posisi berdiri dengan kaki yang pendek, tanpa digambarkan jari-jarinya. Posisi kaki agak direntangkan ke samping, dengan telapak kaki mengarah ke luar. Muka digambarkan bulat, tanpa dilengkapi dengan mata, mulut, alis maupun telinga. Bagian kepala dan tubuh hanya digambarkan bagian luarnya, sedang anggauta badan lainnya dilukis secara penuh dengan warna merah (van Heekeren, 1972: 128, gb. 28.7). Motif manusia lainnya ditemukan dalam sikap berdiri, dengan kaki hanya digambarkan sampai paha, dan tidak sama besarnya. Kedua tangan direntangkan ke samping, tangan yang satu sampai di pinggang sedang tangan lainnya hanya sampai di dada yang pada ujungnya digambarkan bercabang dua. Bagian muka tanpa dilengkapi dengan mata, alis, mulut maupun telinga. Warna yang digunakan adalah merah yang dioleskan pada seluruh permukaan obyek yang dilukis (van Heekeren, 1973: 128, gb. m8).

Lukisan motif manusia dengan warna merah juga ditemukan di pulau Kei, pada dinding batu karang. Di antara motif manusia yang terdapat di daerah itu, ada yang menggambarkan manusia dalam sikap berjongkok dengan kaki terbuka lebar, telapak kaki mengarah ke luar tanpa dilengkapi dengan penggambaran jari-jari. Ke dua tangan diangkat ke atas, setinggi kepala,' dengan telapak tangan terbuka yang dilengkapi dengan jari-jari tangan berjumlah 3 buah. Muka menoleh ke kanan, dengan mata berbentuk bulatan kecil, dan di atas kepala digambarkan beberapa rambut. Bagian tubuh berbentuk bulat telur yang seluruhnya dioles dengan warna merah. Motif manusia lainnya dalam posisi berdiri, dengan kedua kaki direntangkan ke samping. Telapak kaki tidak digambarkan. Tangan kanan memegang perisai, sedang tangan kiri diangkat ke atas melebihi tinggi kepala. Bagian muka tidak dilengkapi mata, alis, hidung dan mulut. Bagian tubuh, kepala dan muka, seluruhnya diisi dengan warna merah. Di samping motif manusia yang digambarkan secara utuh, ada pula motif manusia yang hanya berupa muka, yang digambarkan lengkap dengan mata, alis hidung dan rambut (van Heekeren, 1973: 130. gb. 29).

Contoh lain tentang lukisan motif manusia dapat diketengahkan lukisan motif manusia yang ada di pulau Arguni, Irian Jaya. Motif manusia tersebut digambarkan dalam posisi berdiri, dengan salah satu kakinya agak direntangkan ke samping, sedang kaki lainnya agak dibengkokkan, sehingga memberi kesan posisi berdirinya tidak tegak. Ke dua kaki tidak dileng- 
kapi jari-jari. Kedua tangan diangkat ke atas setinggi bahu, dengan tidak dilengkapi penggambaran telapak tangan dan jari-jari tangan, kepalanya memakai topi berbentuk runcing, sedang bagian muka tidak jelas bagianbagiannya. Genetalia digambarkan menonjol menunjukkan milik laki-laki (van Heekeren, 1973: 132. gb. 34).

Sebagai hasil seni relief, motif manusia bercorak pra sejarah antara lain ada di dinding wadah kubur jenis waruga, di Minahasa (Sulawesi Utara). Di antara motif manusia yang diterapkan, ada yang memiliki ekspresi yang mirip dengan motif manusia yang dilukiskan pada dinding gua dan batu karang. Motif manusia tersebut dalam sikap ke dua kaki direntangkan ke samping dengan lutut agak dibengkokkan, telapak kaki mengarah ke luar. Kedua tangan diangkat ke atas setinggi bahu, sehingga berada di samping kepala. Bagian muka digambarkan lengkap dengan mata, mulut dan telinga, sedang garis hidung menjadi satu dengan garis alis. Genetalia menonjol, menunjukkan milik laki-laki. (Hadi Mulyono, 1976: 57).

Motif manusia dengan gaya yang sama, dikenakan pula pada sarkofagus dari daerah Batutring (Sumbawa), serta pandhusa di daerah Bondowoso (Jawa Timur). Secara garis besar motif manusia itu dapat dimasukkan dalam gaya kangkang, karena kedua kaki direntang ke samping dengan lutut agak dibengkokkan, ke dua tangan diangkat ke atas sebatas telinga. Perbedaan antara ke duanya, adalah jenis kelaminnya. Motif manusia pada sarkofagus menunjukkan laki-laki, dengan genetalia yang menonjol. Sedang motif manusia pada pandhusa, menunjukkan milik wanita dengan tanda buah dada yang menonjol.

Penggambaran motif manusia yang memiliki gaya yang sama dikenakan pula pada kain tenun Sumba. Motif manusia digambarkan dalam posisi berdiri, dengan ke dua telapak kaki mengarah ke luar, jari-jari kaki digambarkan lengkap. Ke dua tangan berada di samping badan, mulai siku dibengkokkan dengan telapak tangan mengarah ke bawah, ibu jari menempel pinggang. Tulang-tulang rusuk digambarkan secara jelas, dilengkapi dengan puting susu, genetalia menonjol. Dari genetalia serta puting susunya dapat diketahui bahwa motif manusia tersebut menggambarkan seorang laki-laki. Penggambaran bagian muka lengkap dengan mata, alis hidung, mulut dan telinga (Hoop, 1975: 95). Dalam seni lukis bentuk lukisan yang menampakkan tulang-tulangnya, disebut lukisan sinar-X ( $\mathbf{X}^{\prime}-\mathbf{R}$ ay). Claire Holt, 1961: 12). 
Dari uraian di atas, diperoleh pengertian bahwa motif manusia di pulau Lomblen sebagai hasil seni lukis, memiliki kesamaan bila dibandingkan dengan hasil seni lukis prasejarah di tempat lain. Baik motif manusia di pulau Lomblen maupun di tempat lain, pada umumnya dilukis tanpa pakaian. Warna yang digunakan adalah warna merah, dengan tidak memperhatikan anatomis atau proporsinya. Dalam segi gaya, pada umumnya kaki direntangkan ke samping, baik dalam posisi berdiri atau berjongkok. Sedang sikap tangan tidak selalu sama, sebagian ada yang diangkat ke atas, sebagian lagi berada di samping badan. Penggambaran bagian muka pada umumnya tidak dilengkapi dengan mata, mulut, dan hidung serta garis alis. Ditinjau dari cara pembuatannya menunjukkan adanya kesamaan, yaitu dilukis dengan kuas yang dioleskan pada seluruh bidang atau permukaan obyek yang dilukis.

Gaya yang sama dapat dilihat pula pada motif manusia, yang diekspresikan sebagai hasil seni relief. Gaya tersebut adalah gaya kangkang, yaitu ke dua kaki direntangkan ke samping dengan lutut dibengkokkan, ke dua tangan diangkat ke atas setinggi bahu. Genetalia digambarkan menonjolkan, sedang bagian muka seperti mata, mulut, hidung, dan alis pada umumnya digambarkan secara jelas. Pada umumnya motif manusia sebagai hasil seni relief, dibuat dengan cara digores atau dipahat dengan alat-alat tajam, dan jarang yang memakai warna.

Kemiripan dalam gaya terdapat pula dalam menggambarkan motif manusia dalam tenun. Dibanding dengan motif manusia yang lain, motif manusia dalam tenun paling mirip dengan motif manusia dari pulau Lomblen. Ke duanya dalam posisi berdiri, kaki direntangkan ke samping dengan telapak kaki mengarah ke luar. Ke dua tangan berada di samping badan, dan genetalianya digambarkan menonjol. Perbedaan antara keduanya, adalah penggambaran tulang rusuk secara jelas pada motif manusia dalam tenun.

Bertolak dari adanya unsur-unsur kesamaan dalam mengekspresikan motif manusia, baik dalam seni lukis, seni relief, maupun dalam tenunan, maka dapat ditarik suatu pengertian bahwa motif manusia yang ditemukan di pulau Lomblen termasuk hasil seni yang bercorak prasejarah. Keberhasilan manusia mengekspresikan sesuatu, selain dapat menghasilkan karya seni, dimungkinkan pula mengandung getaran jiwa yang meyakini adanya kekuatan yang berada di luar dirinya.

Getaran jiwa tersebut, dapat dianggap sebagai unsur keagamaan (religius emotion) yang merupakan pendorong manusia untuk berlaku serba 
religi. Religi menurut $\mathbf{N}$. Bellah dapat dipandang sebagai suatu sistem lambang, yaitu sebagai serangkaian bentuk-bentuk simbol yang dapat menghubungkan manusia dengan kondisi-kondisi yang mutlak bagi eksistensinya (Bellah, 1964: 359). Dengan demikian motif manusia sebagai hasil seni merupakan salah satu simbol, yang diperlukan oleh manusia untuk media komunikasi dengan kekuatan di luar dirinya. S.imbol dapat pula dianggap sebagai pengikat solidaritas (Peursen, 1967: 143-147).

Dalam alam fikiran manusia prasejarah, berlaku suatu anggapan bahwa gambar tidak hanya dianggap sebagai gambar, melainkan dianggap memiliki kekuatan sakti dari tokoh yang digambarkan. Dengan dasar konsep itu, maka motif manusia baik yang sebagai hasil seni, relief, atau dalam tenun, merupakan lambang yang memiliki kekuatan sakti atau su pernatural. Kekuatan sakti itu, antara lain dimiliki oleh nenek moyang. Dengan demikian penggambaran motif manusia, bertujuan untuk memperoleh kekuatan sakti dari nenek moyangnya. Kekuatan sakti tersebut, antara lain adalah kekuatan untuk menolak bala, dan mendatangkan kesuburan.

Berdasarkan uraian di atas, lukisan motif manusia yang ditemukan di pulau Lomblen, dianggap memiliki kekuatan untuk menolak bala, dan dapat mendatangkan kesuburan terutama karena genetalia yang menonjol. Di samping itu, temuan motif manusia di pulau Lomblen merupakan tambahan data tentang hasil seni lukis bercorak prasejarah, dan dapat pula dianggap sebagai data tambahan tentang alam fikiran manusia pada waktu itu, yang berkeyakinan bahwa lambang berfungsi sebagai media komunikasi dengan nenek moyangnya.

\section{Kepustakaan}

Bellah, E.N. 196t Religious Evolution'. American Sosiological Review 1964.

t 1 kin. A.P. The Australian Aborigines: How to Understand Them, Sidney-London, An:us and lyit Robertson

Hadimuljono dkk. "'Laporan Hasil Survai Tentang Waruga dan Peninggalan Kepurbakalaan Lainnya di Daerah Kabupaten Minahasa Propinsi Sulawesi 'Utara", Berita Penelitian Arkeologi No. 3. Jakarta: Pusat Penelitian Purbakala dan Peninggalan Nasional. 1976

Holt, Claire. Art in Indonesia: Continuities and Change. Ithaca New York: Cornell University. 1967

Hoop, A.N.J. Th. a Th van der, Ragam-ragam Perhiasan Indonesia, Konınklijke Batavlaasce 1949 Genootschap van Kunsten en Wetenschappen.

Koent jaranıngrat Pengantar Ilmu Antropologi, Jakarta, Aksara Baru 1983.

Peursen, C.A. van Strategi Kebudayaan, Yogyakarta, Kanisius 1967.

Roder, J "The Rockpaintıngs of the Mac Cluer Bay". The Antiquity and Survival, 1, no. 5, 1959 hal. $387-400$.

Soejono, R.P. "Prehistori Irian Barat" Penduduk Irian Barat, Jakarta Universitas Indo1963 nesia.

Soejono, R.P. (editor) Sejarah Nasional Indonesia, Jilid I, Jakarta, Balaı Pustaka. 1977. 


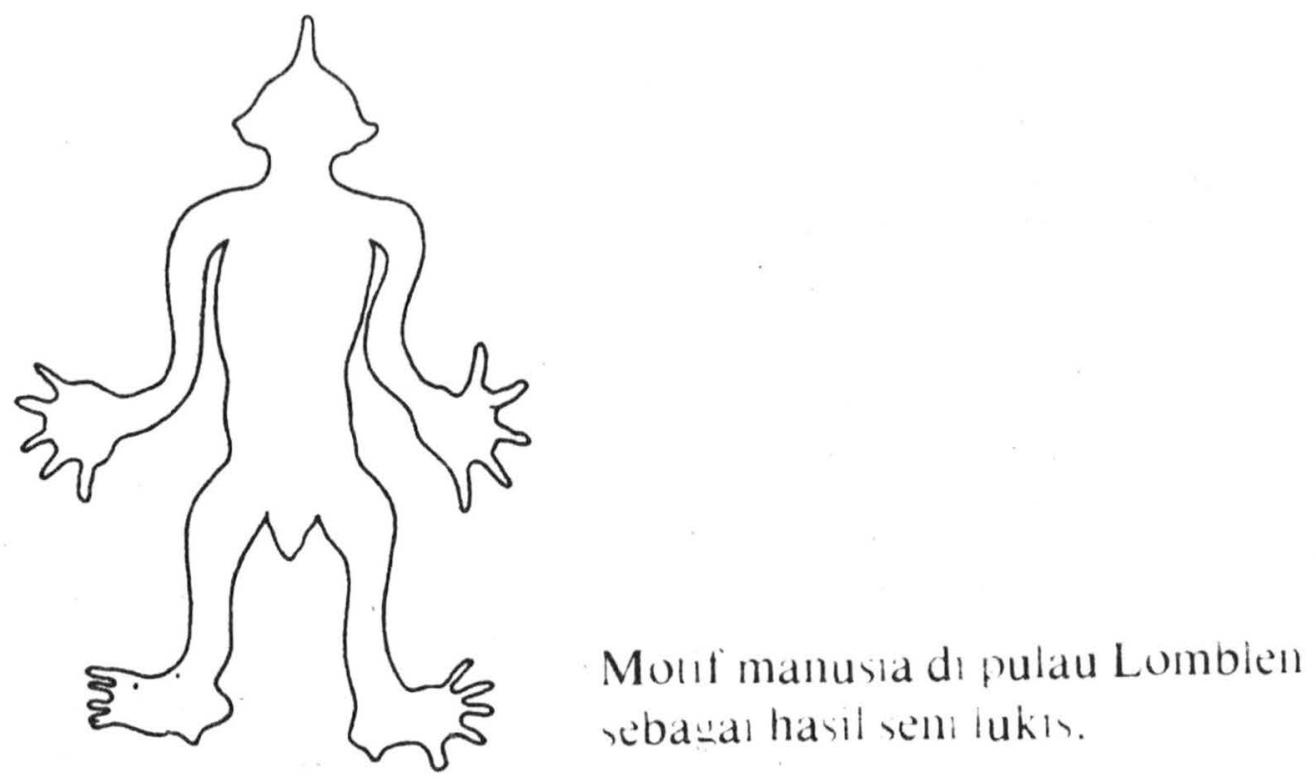

$$
\begin{aligned}
& \text { Molil mallusid di Walluza } \\
& \text { codagd has selli ilicl. }
\end{aligned}
$$
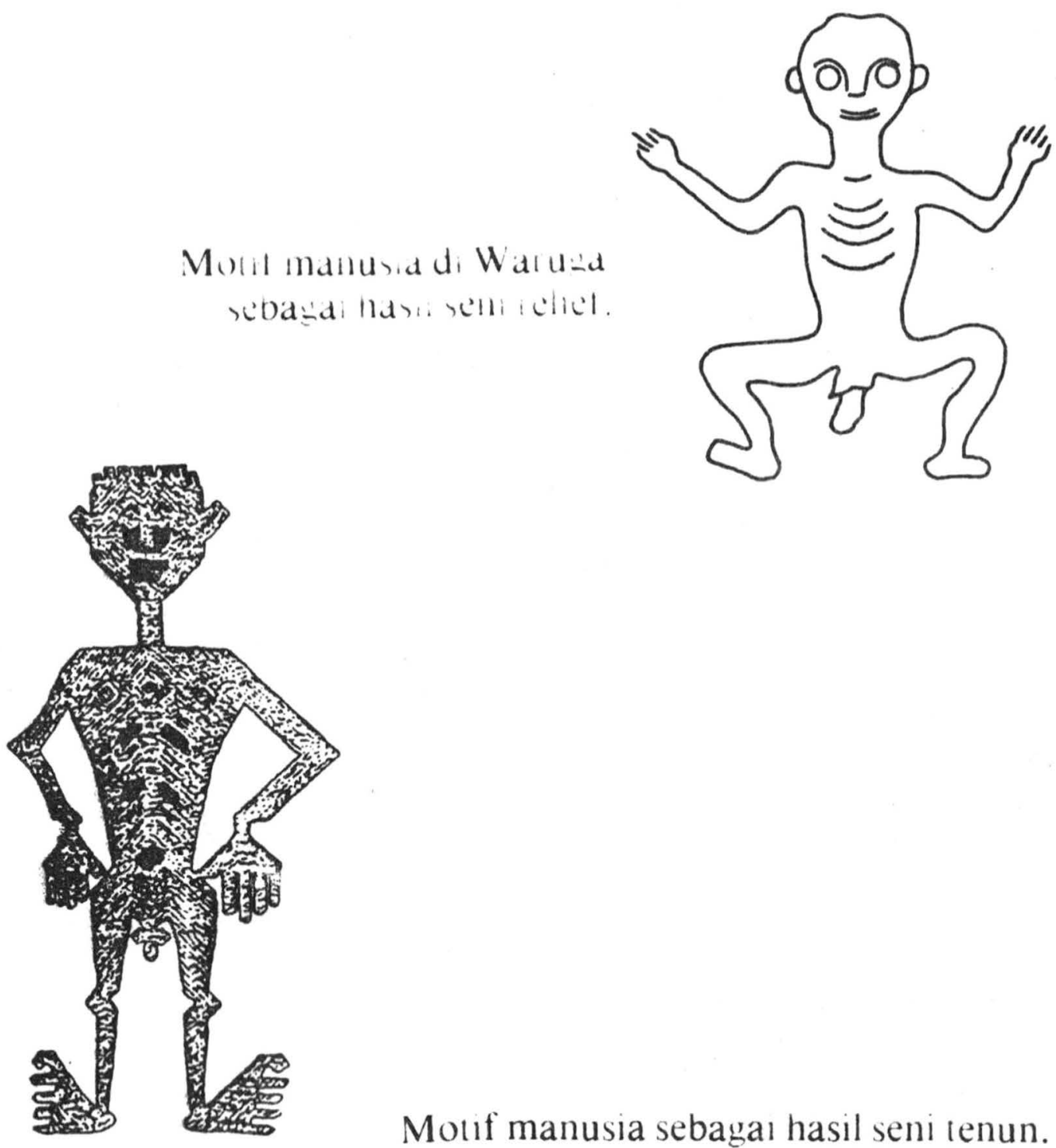

Motif manusia sebagaı hasil seni tenun. 